\title{
Protective effect of blackthorn fruits (Prunus spinosa) against tartrazine toxicity development in albino Wistar rats
}

Igori Balta ${ }^{1} 0$, Bogdan Sevastre ${ }^{2}$, Vioara Mireşan ${ }^{3}$, Marian Taulescu $^{4}$, Camelia Raducu $^{5}$, Adina Lia Longodor ${ }^{3}$, Zamfir Marchiş ${ }^{6}$, Codruta Stefania Mariş ${ }^{7}$ and Aurelia Coroian ${ }^{1 *}$

\begin{abstract}
Background: Tartrazine (Yellow 5 or E102) is a synthetic food dye able to modify perception and behavior, causing agitation, confusion, rhinitis and can produce hyperactivity syndrome in children when is combined with benzoates. Additionally, it can trigger oxidative stress which consequently generates metabolic disorders. Therefore, the study was designed to evaluate the harmful effects of the food additive tartrazine and to observe beneficial properties of blackthorn fruits (Prunus spinosa) on the blood and organs of albino Wistar rats.
\end{abstract}

Materials and methods: This study was carried out on 20 mature Wistar rats, randomly divided into four groups of five animals. Over the course of the experiment, the control group received only food and drinking water, group I received $75 \mathrm{mg}$ of tartrazine dissolved in $(250 \mathrm{ml})$ water group II was given $75 \mathrm{mg}$ of tartrazine and $200 \mathrm{mg}$ of dried blackthorn fruit powder $200 \mathrm{mg}$ dissolved simultaneously in $(250 \mathrm{ml})$ of tartrazine-water mixture (aiming to reduce the tartrazine toxicity) and group III received a higher dose of tartrazine $(100 \mathrm{mg})$ in (250 ml) of water.

Results: At the end of the experiment, values regarding kidney and liver weight were significantly increased, while the weight of the spleen was slightly decreased compared with the weight of the control group. Biochemical and hematological assays, of the blood samples show that the addition of tartrazine in the diet of rats caused significant changes in all biochemical and hematological parameters of the blood. In the group II, which received (P. spinosa) powder combined with tartrazine, the biochemical and hematological parameters had average values similar to the control group.

Conclusions: Histopathological assay showed that the application of tartrazine in the group I, II and III produced lesions of the kidneys, spleen and the liver for all rodents. Tartrazine was able to generate histopathological changes, which caused significantly tissue lesions of the liver and significant changes in blood parameters. Blackthorn powder showed a promising protective role for the blood parameters but demonstrated no significant benefits for the organs.

Keywords: Tartrazine toxicity, Blood biochemistry, Hematology, Rat histopathology, Prunus spinosa

\footnotetext{
*Correspondence: coroian.aurelia@gmail.com

${ }^{1}$ Department of Toxicology, Faculty of Animal Science

and Biotechnology, University of Agricultural Sciences and Veterinary

Medicine, Calea Manastur 3-5, 400372 Cluj-Napoca, Cluj, Romania

Full list of author information is available at the end of the article
}

C The Author(s) 2019. This article is distributed under the terms of the Creative Commons Attribution 4.0 International License (http://creativecommons.org/licenses/by/4.0/), which permits unrestricted use, distribution, and reproduction in any medium, provided you give appropriate credit to the original author(s) and the source, provide a link to the Creative Commons license, and indicate if changes were made. The Creative Commons Public Domain Dedication waiver (http://creativecommons.org/ publicdomain/zero/1.0/) applies to the data made available in this article, unless otherwise stated. 


\section{Introduction}

The meaning of food additive can be defined in a simple way-it is a substance that is not a normal constituent of food, and is added intentionally for a technological, organoleptic or nutritional purpose [1]. As a class of the food additives category, synthetic food dyes should be subjected to numerous investigations such as biochemical, mutagenic and acute toxicity experimental studies of both long and short duration for maximal consumer safety [2]. Using food dyes in the food industry today can produce unintended consequences in terms of safety. Some studies demonstrated the allergenic [3-6], clastogenic [7-9] mutagenic and carcinogenic effects on different dyes, such as: tartrazine, amaranth, Sudan IV, carmoisine, brilliant blue [8]. Tartrazine is a synthetic lemon yellow azo dye primarily used as a food coloring. It is obtained by chemical synthesis from coal tar, and is widely used in the food, cosmetic and pharmaceutical industry [10]. This food additive is linked with provoking asthma attacks and hives in children $[6,11]$. It can also modify perception and behavior, causing agitation, infertility, confusion, rhinitis, migraine [12]. Furthermore, in children, when it is combined with benzoates it could produce hyperactivity syndrome [13] and thyroid tumours [14]. Doses of 0.14 up to $750 \mathrm{mg}$ of tartrazine in people produce effects on peripheral nerves, paresthesia and teeth change. After consuming tartrazine people suffering from asthma, may have side effects, because the tartrazine triggers mast cell degranulation [15-19]. This leads to the release into the body of substances stored in granules (histamine) within the mast cells, which in turn causes the symptoms of an allergic attack.

FAO/WHO established ADI (an acceptable daily intake) for tartrazine of $0-7.5 \mathrm{mg} / \mathrm{kg}$ b.w./day [20]. Tartrazine exposure by inhalation is considered hazardous. This dye is responsible for inducing oxidative stress in rats [21] and that, is associated with free radical production, decreasing significantly biochemical serum parameters and antioxidants of blood. Onion juice (Allium сера) added in the rat diet reduces the toxic effect of tartrazine on the enzymatic activity of antioxidants and biochemical serum parameters. The lethal dose in Wistar rats is $>2000 \mathrm{mg} / \mathrm{kg} /$ b.w. reported by EFSA and others $[20,22]$. Treating pregnant females of mice with $68 \mathrm{mg} /$ kg-b.w. of tartrazine after evaluation of the females together with embryos, presented cytogenetic changes and females had increase in chromosomal aberrations [23]. The dye is able to increase levels of hyperactivity and aggression in the behavior of hyperactive children [24] and induce damage in the thyroid glands of rodents $[25,26]$. In mammalian cells, tartrazine can trigger chromosomal aberrations in bone marrow and can cause an increase of sister chromatid exchanges (SCEs) [9].
Ordinarily, 4-5 sister chromatid exchanges occur for a chromosome pair over one mitosis, whilst 14-100 (SCEs) is not a normal variable and can present a hazard to the organism. A recent study, [27] demonstrated that this synthetic food additive increases the toxicity rate, genotoxicity, mutations and disruption of sex ratio in Drosophila melanogaster model. However, other studies have shown that tartrazine has a potential genotoxic [28] and clastogenic activity.

In Wistar rats and mice the tartrazine can induce chromosomal aberrations in bone marrow [9]. Additionally, other studies have shown that tartrazine has a genotoxic potential effect on leucocytes of rats [28], produces damage in bone marrow cells and affects the DNA in the liver and kidneys of rats [29]. Cytotoxic activity was observed at concentrations of $1,2,4$ and $8 \mathrm{mM}$ on human peripheral blood cells [30].

In the study realized by Mehedi et al. [31] was demonstrated that sub-chronic ingestion of tartrazine at low doses added in water could cause a structural alteration of the spleen and intestine, inducing a depressing effect on the humoral immune response in male mice. According to recent findings $[28,32]$ tartrazine is able to generate ROS (reactive oxygen species), accelerating oxidative stress, modifying the biochemical profiles and structure in the renal and hepatic tissues. After histology examination of male albino rats [32], their livers showed diffuse vacuolar degeneration in the hepatic parenchyma, showed hepatic congestion and hyperplasia in the bile duct epithelium; and in the hepatocytes of some individuals, necrobiosis was detected. The kidneys showed a mononuclear leukocyte infiltration in the renal cortex, a perivascular edema with infiltration of inflammatory cells, congestion of the renal blood vessel with necrobiotic changes.

Blackthorn or sloe (Prunus spinosa) is a spiny shrub from Rosaceae family, is native to Europe, western Asia and northwest Africa, which was locally naturalized in North America and New Zealand [33]. This plant prefers growing on rocky hills, cliffs, forest edges, pastures and it can be found from the plains to the mountain floor $(1000-1600 \mathrm{~m})$ [34]. The flowers are rich in organic acid, flavones, quercetin, kaempferol, magnesium, potassium and glycosides. The fruits of this tree has a high content of polyphenols, sugars, vitamin $\mathrm{C}$, calcium and magnesium salts, organic acids, beta-sitosterol, ferulic acid, anthocyanins, prunicyanine, gumiresines and tannins [35].

It is known that the fruit exerts astringent, diuretic, anti-diarrheal and antidysentery effects. They are recommended for stomach pain, diarrhea, kidney disease, dysentery, biliary dyskinesia, convulsive cough, diseases of cardiovascular system and for digestion stimulation [36, 
37]. Its phytotherapeutic properties can be attributed to various bioactive molecules such as polyphenolic and anthocyanin compounds [35, 36]. Ethanol extracts from sloes of (Prunus spinosa) have a high content of phenolic substances and a high antioxidant activity and it can be used in pharmaceutical and food industry [38].

Polyphenols with anthocyanins have a powerful antioxidant activity, behaving as free radicals in the body, reducing significantly harmful effects of free radicals which are produced by reactive oxygen species $[39,40]$. Based on these findings and the fact that Prunus spinosal blackthorn fruits are a reach rich source of antioxidants, and may exert a potent protective effect in Wistar albino rats, fine fruit powder was included in this study to investigate the curative effects of blackthorn against the impact produced by tartrazine [41-43]. Therefore, the aims of this study were to evaluate the toxicity of the food additive tartrazine and the protective effects of (Prunus spinosa) powder on hematological, biochemical parameters of blood and damage that was induced in organs of Wistar albino rats, after supplementation of tartrazine (dissolved in water) daily over the course of 7 weeks.

\section{Methods}

The tartrazine study was conducted over a 7 -week period, in which albino Wistar rats received food and substances daily ad libitum. Before the experiment started, rats were acclimatised for 2 weeks under the following conditions: (12/12 light-dark cycle, humidity $50 \pm 10 \%$, temperature $22 \pm 1{ }^{\circ} \mathrm{C}$ ), in the Establishment for Laboratory Animals of the University of Agricultural Science and Veterinary Medicine, Cluj, Romania. They were allowed to free access to standard food and water. All the experimental procedures comply with Directive 2010/63/EU and national legislation (Law no. 43/2014) $[44,45]$. The project was approved by the institutional Research Ethics Committee (approval no. 110/23.04.2018) and authorized by regional state veterinary authority (authorization no. 8187/18.04.2018).

\section{Experimental design}

Animals were randomly divided into 4 groups and each group had 5 animals per cage. The treatment were: (I) control group $(C)$ received only food and drinking water for the full term of experiment; (II) group I received $75 \mathrm{mg}$ of tartrazine dissolved in $250 \mathrm{ml}$ of water; (III) Group II received $75 \mathrm{mg}$ of tartrazine dissolved in drinking water and further, $200 \mathrm{mg}$ of (Prunus spinosa) fine powder was added and mixed thoroughly in the tartrazine-water mixture $(250 \mathrm{ml})$; (IV) group III was subjected to the highest concentration of tartrazine $(100 \mathrm{mg})$ in water $(250 \mathrm{ml})$. The dry extract of (Prunus spinosa) was administrated only in the diet (drinking water) of group II in order to diminish toxic effects of tartrazine. After 7 weeks of administering tartrazine, the individuals were again weighed.

\section{Chemicals}

Tartrazine (Fig. 1), Trisodium-5-hydroxy-1-(4sulfonatophenyl)-4-(4-sulfonatophenylazo)-Hpyrazole3-carboxylate, an azo dye as orange colored powder (CI Number $=19,140$, EEC Number $=E-102$ ), with molecular formula $\mathrm{C}_{16} \mathrm{H}_{9} \mathrm{~N}_{4} \mathrm{Na}_{3} \mathrm{O}_{9} \mathrm{~S}_{2}$ is water-soluble and meets the standardized requirements. From the present study, tartrazine was purchased from Stera Chemicals (Bucharest, Romania) $[46,47]$.

\section{Fruit samples}

Fresh blackthorn fruits were collected at full maturity at the end of September, from the $\left(45^{\circ} 08^{\prime} 23.8^{\prime \prime} \mathrm{N}\right.$ $24^{\circ} 15^{\prime} 23.8^{\prime \prime} \mathrm{E}$ ) Vlăduceni, Commune Păușești Măglași, V^alcea County, Romania. Prunus spinosa fruits were recognized by horticulturist Dr. Adrian Vescan, at the Department of Horticulture on the territory of the University of Agricultural Sciences and Veterinary Medicine, Cluj-Napoca. The Prunus spinosa fruits were chosen due to their beneficial properties of bioactive compounds [41-43]. Plant material was washed, the stones (seeds) were removed, and proper pulp was dried at $30{ }^{\circ} \mathrm{C}$ in a drying oven (Memmert Lab Oven UFB $4001400 \mathrm{~W}$, Germany). After that, obtained dried pulp was milled in order to achieve the proper pulp fine powder.

\section{Blood sample and organ collection}

Finally, all animals were subject to deep narcosis using isoflurane and blood samples were collected from the orbital sinus for biochemical and hematology analysis. Blood samples were collected in vacutainers containing EDTA. Later the animals were euthanized by prolonged narcosis, the animals were considered dead when no heart and respiratory activity was recorded. The irreversibility of phenomena was assured by cervical dislocation. Organs such as liver, spleen, kidneys and brain were collected and frozen at a $-20{ }^{\circ} \mathrm{C}$ in order to realize histopathological examinations.

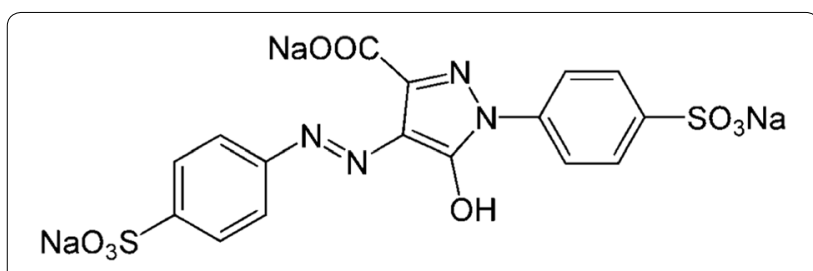

Fig. 1 Chemical structure of tartrazine (E102) [52] 


\section{Clinical biochemistry}

Biochemical determinations of blood samples were performed with a semiautomated screen-type biochemical analyzer STAT-FAX 1904 Plus, Global Medical Instrumentation, Inc., 6511 Bunker Lake Blvd., Ramsey Minnesota, 55303 USA. The following parameters were measured: Aspartate aminotransferase (AST), Alanine aminotransferase (ALT), Glucose (GLU), Cholesterol (COL), Triglyceride (TG) and Creatinine (CRE) using special kits following the producer specifications [48].

\section{Hematology}

Hematological measurements were performed by using 5-Part Differential, performed on the Abacus Junior Vet Analyzer, Diatron, (Messtechnik, Budapest, Hungary). This device evaluated 18 hematological parameters, from $(n=20)$ samples, using $(n=5)$ replicates for each group requiring just $25 \mu \mathrm{l}$ of blood sample.

\section{Histopathology}

Samples from liver, kidney, spleen and brain were collected and fixed in 10\% phosphate-buffered formalin for $24 \mathrm{~h}$, routinely processed, embedded in paraffin wax, cut into 3-4 $\mu \mathrm{m}$ sections and stained with hematoxylin and eosin (H\&E). Samples were examined using an Olympus BX51 microscope. Photomicrographs were taken using Olympus SP 350 digital camera and Cell^ ${ }^{\wedge}$ basic imaging software (Olympus Corporation, Japan) [29]. Histological changes, including degenerative processes, necrosis, inflammation, and cell proliferation were evaluated in all samples.

\section{Statistical analysis}

The normal distribution of the values for each biochemical parameter (AST, ALT, glucose, cholesterol, triglyceride, creatinine), hematological parameters (WBC, LYM, MON, NEU, LYM, MO, NE, RBC, HCB, HCT, MCV, $\mathrm{MCH}, \mathrm{MCHC}$, RDWc, PLT, PCT, MPV, PDWc) and morphological parameters (initial and final weight, liver, right and left kidney, spline and brain weight) were verified using the Shapiro-Wilk test. The average for each parameter is the arithmetic mean of five replications and it was examined using data from five repetitions with an ANOVA model (JMP version 12, SAS Institute, USA) that included terms for biochemical, hematological and histopathological parameters. Significant differences among groups (control, I, II and III) means were further examined using Tukey's multiple range test at the 0.05 probability level. A $p$-value of 0.05 was used as the threshold for statistical significance.

\section{Determination of total phenolics}

The total amount of polyphenols in Blackthorn fruit extracts was investigated using adjusted Folin-Ciocalteu colorimetric method $[49,50]$. The method is based on the polyphenol reducing properties of the hexavalent molybdenum of the polyphosphomolybdate contained in the Folin-Ciocalteu reagent. Hexavalent molybdenum is partially reduced by polyphenols in a strongly acidic medium at a lower valence state $(+4,+5)$, which in alkaline medium is colored in blue (presenting absorption bands at $750 \mathrm{~nm}$ ). Absorption is formed due to the charge transfer bands, specific for transition metals situated in low valence states in the mixture. Folin-Ciocalteu reagent $(2 \mathrm{M})$ is diluted $1: 10$ and in $7.5 \%$ sodium carbonate solution for neutralization and alkalinization of the reaction medium. Preparation of the calibration curve was achieved by mixing $2.5 \mathrm{ml}$ of Folin-Ciocalteu reagent diluted $1: 10$ or with $0.2: 0.4 ; 0.6 ; 0.8 ; 1.2 \mu \mathrm{M} / \mathrm{ml}$ gallic acid. The initial yellow solution Folin-Ciocalteu slightly becomes green once with the increase in gallic acid concentration. After aprox $10 \mathrm{~min}$, the time required to complete the redox reaction, $2 \mathrm{ml}$ of $7.5 \%$ sodium carbonate solution is added to neutralize and alkalinize the reaction medium, followed by the formation of reduced polyphosphomolybdate, colored in blue. After $2 \mathrm{~h}$ of incubation in the dark room, the absorbance is read at $750 \mathrm{~nm}$. The concentration of polyphenols is expressed using the calibration curve plotted at different concentrations of gallic acid. The analyzed samples ( $25 \mu \mathrm{l}$ each) were dissolved in methanol and further dilution was effectuated to obtain readings within the standard curve made with gallic acid $(R=0.997)$. The extracts were oxidized by the Folin-Ciocalteu reagent $(120 \mu \mathrm{l})$ and the neutralization was done with $\mathrm{Na}_{2} \mathrm{CO}_{3}(340 \mu \mathrm{l})$ after $5 \mathrm{~min}$. Absorbance was read at $750 \mathrm{~nm}$ after $90 \mathrm{~min}$ in the dark at room temperature. The results were expressed in milligram of gallic acid/g dry matter of plant (mg GAE/g DW plant material).

\section{Total monomeric anthocyanin content}

The differential $\mathrm{pH}$ method is the most widely used method for determining anthocyanin content $[49,51]$. To obtain the extract, $3 \mathrm{~g}$ of Prunus spinosa pulp fine powder were weighed and homogenized in $10 \mathrm{ml}$ of acidified methanol $(85: 15 \mathrm{v} / \mathrm{v}, \mathrm{MeOH}: \mathrm{HCl})$ for $1 \mathrm{~min}$ at 20,000 RPM using a homogenizer (Ultra-Turrax Miccra D-9 KT Digitronic, Germany). Thus, the sample was centrifuged at $3500 \mathrm{rpm}$ for $10 \mathrm{~min}$. The extract was separated from the residue and re-extracted until the extraction solvent became colorless (total solvent volume was between 100 and $250 \mathrm{ml}$ ). The obtained extracts were combined in a total extract, and the moisture was removed using a rotary evaporator (R-124, Buchi, Switzerland) at $40{ }^{\circ} \mathrm{C}$. 
In the dried samples $10 \mathrm{ml}$ of methanol was added then centrifuged at $5000 \mathrm{rpm}$ and filtered with a $0.45 \mu \mathrm{m}$ filter (Millipore). Blackthorn extracts were dissolved in methanol then diluted with $0.025 \mathrm{~mol} / \mathrm{l}$ potassium chloride (adjusted with $\mathrm{HCl}$ to $\mathrm{pH} 1.0$ ) and $0.4 \mathrm{~mol} / \mathrm{l}$ sodium acetate ( $\mathrm{pH} 4.5)$. Each sample and standard (cyanidin3 -glucoside) was diluted with buffer solution $\mathrm{pH}=1$ and the absorbance was read at $520 \mathrm{~nm}$ and $700 \mathrm{~nm}$, respectively, using a UV spectrophotometer (Jasco V-630, International Co Ltd, Japan). An aliquot of each sample was diluted to the same value with the buffer solution $\mathrm{pH}$ 5.0 and measured at 520 and $700 \mathrm{~nm}$. The results were expressed as mg cyanidin-3-glucoside chloride per dry matter of plant (C3GE mg/g DW). Absorbance values were calculated according to the formula:

$$
\mathrm{A}=\left(\mathrm{A}_{\lambda} 520-\mathrm{A}_{\lambda} 700\right) p H 1.0-\left(\mathrm{A}_{\lambda} 520-\mathrm{A}_{\lambda} 700\right) p H 4.5
$$

Total anthocyanin content means were calculated as follows:

$$
\mathrm{TA}=\mathrm{A} \times \mathrm{MW} \times \mathrm{DF} \times 1000 / \varepsilon \times 1
$$

\section{Results}

\section{Biochemical analysis}

The average values and standard deviation of blood serum parameters as AST, ALT, GLU, COL, TG and CRE obtained from biochemical analysis of blood are shown in Table 1.

The biochemical analysis of blood showed significant variations of GLU $(\mathrm{mg} / \mathrm{dl})$ depending on the tartrazine dose applied.

Significant values were obtained in the group III $(200.24 \pm 1.08)$ and the group I $(191.76 \pm 1.07)$ compared to the control group $(181.96 \pm 2.13)$. The values of total COL $(\mathrm{mg} / \mathrm{dl})$ did not show significant differences between groups. Regarding to TG $(\mathrm{mg} / \mathrm{dl})$, the significant values were observed in the group III $(67.58 \pm 1.33)$, which received the highest dose of food dye. TG values showed non-statistically significant differences among the control group, I and II (Table 1). According to Arefin et al. significantly increased levels of CRE and TG are reported in Swiss mice, after applying tartrazine dose $400 \mathrm{mg} / \mathrm{kg}$ b.w. by oral gavage [52].

In the present study AST (U/l) showed statistically significant means in the group I $(114.14 \pm 1.44)$ and III (119.88 \pm 1.43$)$ compared to the control group $(109.18 \pm 0.92)$ and the group II with fruit pulp powder (108.42 \pm 0.53$)$. The highest dose of tartrazine was able to significantly increase the level of ALT (U/l) for the group III $(63.54 \pm 0.66)$ and for the group I $(62.42 \pm 0.67)$ compared to the control group $(54.44 \pm 0.60)$, respectively. In contrary, the application of dried fruit powder mixed in drinking water in the (group II) determined a greater effectiveness reducing ALT (U/l) $(56.85 \pm 0.57)$ values, modifying them similarly to control group. Elevated levels of enzymes such as AST and ALT liberated into the bloodstream are directly correlated with damaged tissues of liver and heart [53]. Regarding CRE (mg/dl), the significantly increased values were registered for group III $(0.53 \pm 0.02)$ followed by the group I $(0.49 \pm 0.03)$, II $(0.44 \pm 0.01)$ compared to the control group $(0.41 \pm 0.01)$, respectively.

Similar results with the present study were found in the study realized by Himri et al. [54], who measured AST $(\mathrm{U} / \mathrm{l})(165.16 \pm 17.82)$ and ALT $(62 \pm 2.84)$ in groups of rats that received a tartrazine dose of $10 \mathrm{mg} /(\mathrm{kg} \mathrm{b.w.)}$ and was significantly higher compared to the control group

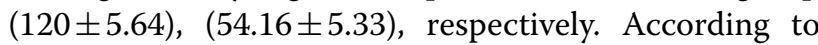
results of Alaa Ali et al. [32], the addition of tartrazine in water could greater increase parameters as Urea, AST and ALT. Khayyat et al. reported significantly increased biomarkers means of ALT, AST, urea, and CRE after administering tartrazine to rats [28].

Moreover, El-Desoky et al. attributed the increase of concentrations of TG, COL, AST, ALT and CRE in blood serum due to the application of tartrazine in rats compared to the control group [55]. Furthermore, AlSeeni et al. reported that applied doses of $10 \mathrm{mg} / \mathrm{kg}$ b.w. of tartrazine in rat diet, showed a significant increase in biochemical markers as: ALT $(77.16 \pm 1.68 \mathrm{U} / \mathrm{l})$, AST $(79.16 \pm 1.57 \mathrm{U} / \mathrm{l}), \quad$ ALP $\quad(275.83 \pm 3.56 \mathrm{U} / \mathrm{l})$, and TG

Table 1 Average values and standard deviation for each biochemical parameter: AST, ALT, GLU, COL, TG and CRE

\begin{tabular}{lccc}
\hline Parameter & Control & Group I & Group II \\
\hline AST $(\mathrm{U} / \mathrm{l})$ & $109.18 \pm 0.92 \mathrm{c}$ & $114.14 \pm 1.44$ & $108.42 \pm 0.53 \mathrm{c}$ \\
$\mathrm{ALT}(\mathrm{U} / \mathrm{l})$ & $54.44 \pm 0.60$ & $62.42 \pm 0.67 \mathrm{a}$ & $56.85 \pm 0.57$ \\
$\mathrm{GLU}(\mathrm{mg} / \mathrm{dl})$ & $181.96 \pm 2.13 \mathrm{c}$ & $191.76 \pm 1.07$ & $187.36 \pm 1.07 \mathrm{bc}$ \\
COL $(\mathrm{mg} / \mathrm{dl})$ & $67.95 \pm 0.53$ & $69.64 \pm 0.24$ & $68.28 \pm 0.42$ \\
TG $(\mathrm{mg} / \mathrm{dl})$ & $51.68 \pm 0.76 \mathrm{c}$ & $54.7 \pm 1.38$ & $51.38 \pm 0.94 \mathrm{c}$ \\
CRE $(\mathrm{mg} / \mathrm{dl})$ & $0.41 \pm 0.01 \mathrm{c}$ & $0.49 \pm 0.03 \mathrm{ab}$ & $0.44 \pm 0.01 \mathrm{bc}$ \\
\hline
\end{tabular}

Data represents the mean \pm standard deviation $(n=5)$. Within columns, means followed by the same letter $(a$, b or $c)$ are not significantly different between treatments according to the Tukey test $(p=0.05)$; While, within columns means followed by the different letter $(\mathrm{a}, \mathrm{b}$ and $\mathrm{c})$ are significantly different between treatments according to the Tuckey's test $(p=0.05)$. ns: not significant; significant at the 0.05 probability level 
$(224.67 \pm 3.25 \mathrm{mg} / \mathrm{dl})$ compared with the control group [56]. In addition, concurrent treatment of rats with Nigella sativa oil demonstrated a curative effect on biochemical and histological parameters.

\section{Hematological analysis}

After the treatment period, the hematology investigations revealed significant changes in blood serum parameters for rats treated with tartrazine. The main results are presented in Table 2.

The percentages of LYM were very similar for the control group (38.22 \pm 3.05$)$ and the group II (36.42 \pm 1.54$)$, while the group I $(47.34 \pm 4.62)$ and III $(53.36 \pm 3.08)$ showed a significant increase in LYM\% compared to the control group (Table 2). The significant differences were observed in $\mathrm{MO} \%$ between the control group $(1.44 \pm 0.24)$ and the group III $(4.46 \pm 0.26)$ (Table 2), which received the highest intake $(100 \mathrm{mg})$ of dye.

A significant decrease was observed in NE\% count in the group III $(40.76 \pm 1.40)$ compared to the control $(52.22 \pm 4.54)$, whilst group II, which received blackthorn fruit powder, had more elevated percentage $(56.52 \pm 3.65)$ of NE compared to the control group. According to Himri et al., this food dye increased significantly the number of neutrophils in rat blood [54]. A significantly lower PLT $\left(10^{9} / 1\right)$ count was found in the group III $(502.6 \pm 90.83)$ treated with $100 \mathrm{mg}$ of tartrazine compared to the control group $(681 \pm 69.56)$. In the study of Himri et al., applying tartrazine at a dose of $7.5 \mathrm{mg} /(\mathrm{kg}$ b.w.) was able to significantly lower PLT $\left(10^{3} / \mu \mathrm{l}\right)$ count $(609.83 \pm 45.58)$ compared to the control group (725.00 \pm 11.56$)$.

HGB (g/dl) in group II (13.68 \pm 0.79$)$, which received fruit extract, has approached values of the control group $(14.4 \pm 0.80)$ (Table 2). While, the groups I $(12.46 \pm 0.40)$ and III $(12.56 \pm 0.24)$ had a slight decrease of this measured parameter compared to the control group (Table 2). WBC $\left(10^{9} / \mathrm{l}\right)$ increased significantly in the group treated with the highest dose of tartrazine compared to the control group (Table 2). There were no significant changes regarding LYM, MON, RBC, HCT, MCV, RDWC, PCT, MPV and PDW. An average amount of $\mathrm{MCH}$ (pg) found in the red blood cells of rats did not reveal significant changes in the group II $(17.1 \pm 0.64)$ compared to the control $(17.42 \pm 0.88)$. Moreover, $\mathrm{MCH}$ in the group I $(15.44 \pm 0.51)$ and group III $(16.4 \pm 1.27)$ showed a significant reduction compared to control and group II.

\section{Body weight and organ weight evaluations}

In the present study, during the experiment no mortality cases were observed. The weights of the organs as liver, brain, spleen and kidneys are presented in Table 3.

Table 2 Average values and standard deviation for hematological measurements of Wistar rats treated with tartrazine for 7 weeks

\begin{tabular}{|c|c|c|c|c|}
\hline Parameter & Control & Group I & Group II & Group III \\
\hline WBC $10^{9} / 1$ & $4.8 \pm 0.85 a b$ & $5.35 \pm 1.38 \mathrm{ab}$ & $3.85 \pm 0.77 b$ & $5.87 \pm 0.93 a$ \\
\hline LYM $10^{9} / /$ & $2.05 \pm 0.44 a b$ & $2.79 \pm 0.93 a$ & $1.55 \pm 0.43 b$ & $3.06 \pm 0.36 a$ \\
\hline MON $10^{9} / \mathrm{I}$ & $0.45 \pm 0.18 a$ & $0.15 \pm 0.09 b$ & $0.26 \pm 0.14 a b$ & $0.35 \pm 0.21 a b$ \\
\hline NEU $10^{9} / /$ & $2.86 \pm 0.53$ & $2.61 \pm 0.68$ & $2.15 \pm 0.37$ & $2.47 \pm 0.44$ \\
\hline MO\% & $1.44 \pm 0.24 c$ & $2.02 \pm 0.70 c$ & $3.48 \pm 0.25 b$ & $4.46 \pm 0.26 a$ \\
\hline NE\% & $52.22 \pm 4.54 a b$ & $46.98 \pm 6.27 b c$ & $56.52 \pm 3.65 a$ & $40.76 \pm 1.40 c$ \\
\hline $\mathrm{RBC} 10^{12} / \mathrm{I}$ & $7.86 \pm 1.10$ & $7.70 \pm 0.59$ & $7.82 \pm 0.46$ & $7.56 \pm 0.69$ \\
\hline $\mathrm{HGB}$ g/dl & $14.4 \pm 0.80 a$ & $12.46 \pm 0.40 a$ & $13.68 \pm 0.79 b$ & $12.56 \pm 0.24 b$ \\
\hline НСТ\% & $37.82 \pm 5.10$ & $36.97 \pm 3.45$ & $41.04 \pm 2.21$ & $37.07 \pm 2.23$ \\
\hline MCV fl & $48.2 \pm 1.30 \mathrm{ab}$ & $47.2 \pm 1.64 b$ & $50.6 \pm 1.34 a$ & $50.2 \pm 2.59 \mathrm{ab}$ \\
\hline $\mathrm{MCH}$ pg & $17.42 \pm 0.88 a$ & $15.44 \pm 0.51 b$ & $17.1 \pm 0.64 a$ & $16.4 \pm 1.27 a b$ \\
\hline $\mathrm{MCHC} g / \mathrm{dl}$ & $36.16 \pm 1.28 a$ & $32.52 \pm 1.29 b$ & $33.5 \pm 0.41 b$ & $34.2 \pm 1.64 a b$ \\
\hline RDWc\% & $18.52 \pm 0.65 a$ & $18.72 \pm 0.75 a$ & $16.74 \pm 0.69 b$ & $17.14 \pm 0.51 b$ \\
\hline PLT 10ª & $681 \pm 69.56 b$ & $729.6 \pm 32.25 \mathrm{ab}$ & $866 \pm 143.27 a$ & $502.6 \pm 90.83 c$ \\
\hline РCT\% & $0.52 \pm 0.09 a b$ & $0.41 \pm 0.13 b$ & $0.65 \pm 0.14 a$ & $0.33 \pm 0.09 b$ \\
\hline LYM\% & $38.22 \pm 3.05 c$ & $47.34 \pm 4.62 b$ & $36.42 \pm 1.54 c$ & $53.36 \pm 3.08 a$ \\
\hline MPV fl & $7.6 \pm 0.57 a$ & $6.92 \pm 0.13 a b$ & $7.32 \pm 0.48 a b$ & $6.84 \pm 0.29 b$ \\
\hline PDWC\% & $34.72 \pm 0.97$ & $33.2 \pm 0.70$ & $34.36 \pm 1.40$ & $33.36 \pm 0.59$ \\
\hline
\end{tabular}

Data represents the mean \pm standard deviation $(n=5)$. Within columns, means followed by the same letter $(a$, b or $c)$ are not significantly different between treatment according to the Tuckey's test $(p=0.05)$. While, within columns means followed by the different letter $(\mathrm{a}, \mathrm{b}$ and $\mathrm{c})$ are significantly different between treatments according to the Tuckey's test $(p=0.05)$. ns: not significant; significant at the 0.05 probability level 
Table 3 Average values and standard deviation of body weight and organ weight of experimental Wistar rats

\begin{tabular}{llccc}
\hline Parameter & Control & Group I & Group II & Group III \\
\hline Initial weight (g) & $194.2 \pm 5.0$ & $195.6 \pm 7.70$ & $192.8 \pm 4.32$ & $193.8 \pm 5.36$ \\
Final weight (g) & $229.4 \pm 9.11$ & $231.1 \pm 8.97$ & $229.8 \pm 3.77$ & $239.4 \pm 7.60$ \\
Liver (g) & $7.87 \pm 0.58$ & $8.4 \pm 0.76$ & $8.13 \pm 0.51$ & $8.83 \pm 0.30$ \\
Right kidney (g) & $0.75 \pm 0.45 \mathrm{c}$ & $0.91 \pm 0.08 \mathrm{~b}$ & $0.81 \pm 0.07 \mathrm{bc}$ & $1.108 \pm 0.69 \mathrm{a}$ \\
Left kidney (g) & $0.76 \pm 0.06 \mathrm{c}$ & $0.92 \pm 0.07 \mathrm{~b}$ & $0.82 \pm 0.06 \mathrm{bc}$ & $1.106 \pm 0.69 \mathrm{a}$ \\
Spline (g) & $0.62 \pm 0.04$ & $0.64 \pm 0.17$ & $0.60 \pm 0.08$ & $0.57 \pm 0.03$ \\
Brain (g) & $1.60 \pm 0.14 \mathrm{ab}$ & $1.44 \pm 0.04 \mathrm{~b}$ & $1.52 \pm 0.06 \mathrm{~b}$ & $1.76 \pm 0.15 \mathrm{a}$ \\
\hline
\end{tabular}

Data represents the mean \pm standard deviation $(n=5)$. Within columns means followed by the same letter are $(a, b$ or $c)$ are not significantly different between treatments according to the Tuckey's test $(p=0.05)$. While, within columns means followed by the different letter $(a, b$ and $c)$ are significantly different between treatments according to the Tuckey's test $(p=0.05)$
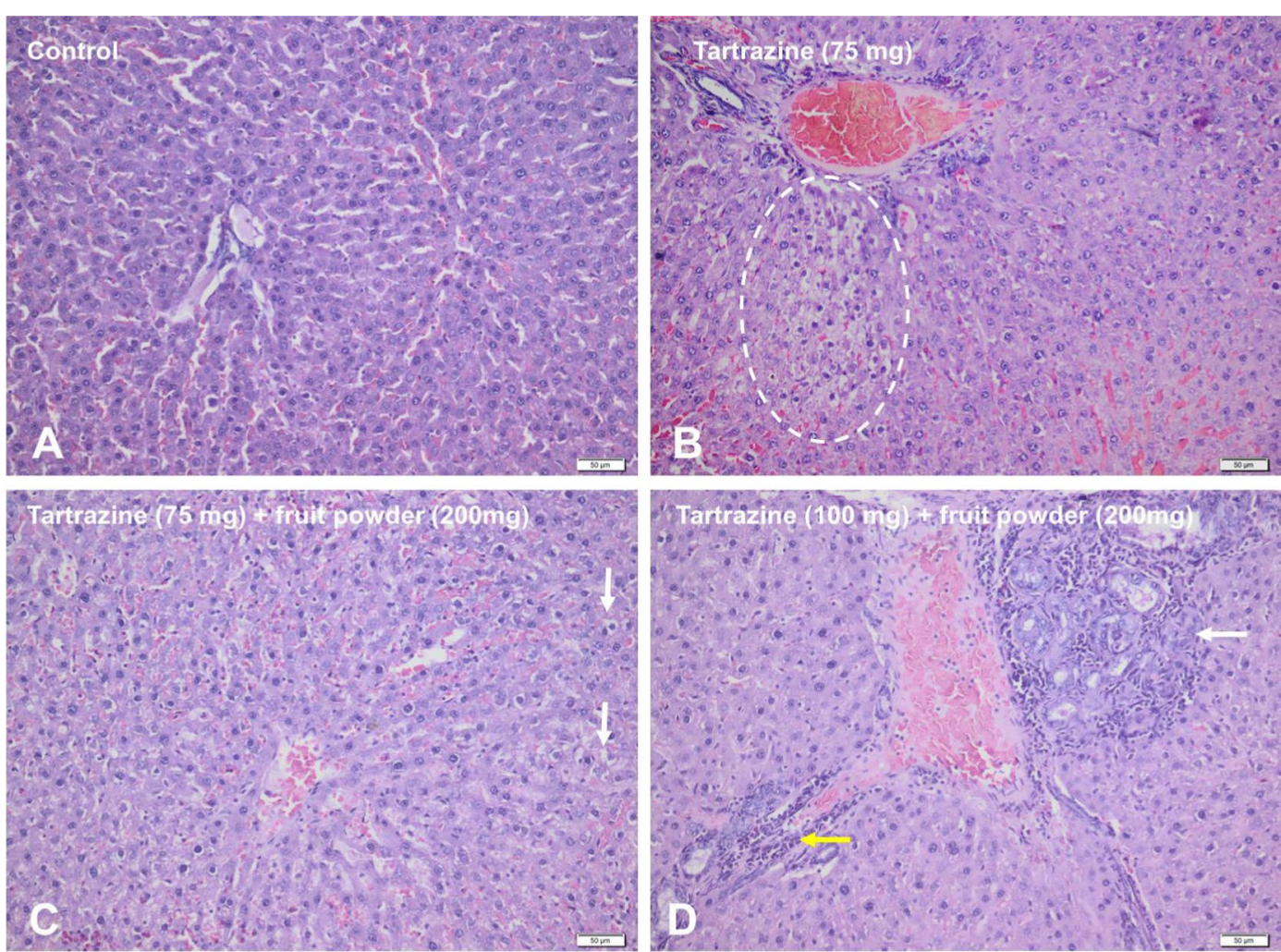

Fig. 2 Microscopical findings of the liver from experimental albino Wistar rats. A Normal features in control group. B Hepatic congestion and hepatocellular vacuolar degeneration and necrosis of the periportal area (delimited zone), group I. C Hepatic congestion and mild vacuolar degeneration of the periportal hepatocytes (white arrows), group II. D Bile duct hyperplasia (white arrow) and mixed inflammatory infiltration of the portal tract, group III (yellow arrow). Hematoxylin-Eosin (H\&E) stain

Body weight and relative weight of the liver, kidneys, brain and spline of rats for the group III, which received a high dose of tartrazine were slightly increased compared to other groups. After 7 weeks of exposure of animals to tartrazine there were no significant weight differences observed between the final weight of the groups. Kidneys, brain and liver weights showed differences among the groups (Table 3).

\section{Histological evaluation}

In the control group, no important structural changes were noted in the liver (Fig. 2A), spleen, kidneys and brain.

In the group I, treated with $75 \mathrm{mg}$ of tartrazine diluted in $250 \mathrm{ml}$ of water, the microscopical examination showed severe hepatic congestion, mild Kupffer cell proliferation, vacuolar degeneration of the hepatocytes 
and individual cell necrosis in the periportal area, bile duct hyperplasia, mild fibrosis and periductal mixed inflammatory cell infiltration (Fig. 2B). The histological changes of kidneys were mild and moderate and consisted of glomerular congestion, interstitial congestion and edema, and mild vacuolar degeneration of renal proximal convoluted tubules (personal communications Balta et al.). No significant changes were identified in the spleen and brain. In group II, treated with $75 \mathrm{mg}$ of tartrazine and $200 \mathrm{mg}$ of fruit powder, the hepatic changes were significantly decreased and included hepatic congestion, mild Kupffer cell hyperplasia and mild periportal vacuolar degeneration (Fig. 2C). Kidney tissues of the group I, showed mild renal congestion and hydropic degeneration of renal tubular epithelium (personal communications Balta et al.). No significant changes were identified in the other examined organs.

In group III, treated with $100 \mathrm{mg}$ of tartrazine and $200 \mathrm{mg}$ of fruit powder, the histological changes of the liver and kidneys were significantly higher compared to the other groups. The hepatic parenchyma showed severe bile duct hyperplasia, portal inflammation and mild fibrosis (Fig. 2D). The kidneys showed glomerular congestion, mild interstitial edema and mixed inflammatory infiltration and vacuolar degeneration of proximal convoluted tubules (personal communications Balta et al.). In the spleen of the rats in group III, numerous lymphoid hyperplasia, hemosiderinladen macrophages and extramedullary hematopoiesis were identified (personal communication Balta et al.). Microscopical examination of the brain tissue revealed congestion, spongy status of the cerebral gray matter and mild gliosis (personal communications Balta et al.).

\section{Total polyphenolic and anthocyanin content}

Total anthocyanins and polyphenols content from blackthorn fruits are presented in (Fig. 3). The total polyphenols content was revealed using the Folin-Ciocalteu method $[49,50]$ and total monomeric anthocyanin content was determined by the differential $\mathrm{pH}$ method. The

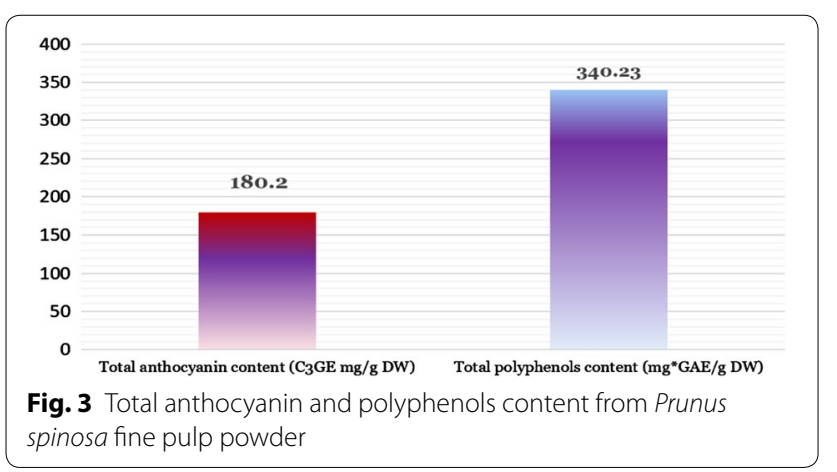

total polyphenolic and anthocyanin content in analyzed Blackthorn extract presented values of 340.23 (mg GAE/g DW) and 180.2 (C3GE mg/g DW), respectively.

\section{Discussion}

The most significant changes of the liver and kidneys specimens after 7 weeks of tartrazine exposure were observed in group III. Our deduction is that this dye can act through stasis. The application of the highest dose (100 mg diluted in $250 \mathrm{ml}$ of water) was able to cause hepatic congestion, bile duct hyperplasia and mixed infiltration into the portal spaces in the liver of group III. In a study, tartrazine demonstrated toxic effects on male albino rats, presenting diffuse vacuolar degeneration in the hepatic parenchyma, hepatic congestion and hyperplasia in the bile duct epithelium, and in the hepatocytes of some individuals, necrobiosis was detected [32].

Histopathological results from the present study are in concordance with those reported by Al-Seeni et al. that observed atrophic tubular degeneration with lining and congested glomeruli in kidney tissue and broad infiltration of the lymphocytes in the liver of the tartrazine treated rats compared to the control group [56]. A study conducted by Ghonimi et al. aimed to test the subchronic toxicity of tartrazine and the protective effects of both royal jelly and cod liver oil in some parenchymal organs of Wistar rats [57].

After application of tartrazine theraphy for 30 days at dose of $500 \mathrm{mg} / \mathrm{kg}$ by gavage, histological investigations showed modifications in the liver, brain, stomach, kidneys and testes. The liver was damaged, and necrosis of hepatic tissue, severe steatosis, diffuse degeneration, fibrous tissue proliferation with anti-inflammatory cells in the portal area and moderate disorganization of hepatic cords was showed. In the group II, testis examination showed proliferation and hyperplasia of the interstitial Leydig cells with vacuolations. Furthermore, vacuolization in the brain tissues, especially in white matter and degenerative changes in the stomach mucosa was observed. In the kidneys, hyaline degeneration was detected in renal tubules and vacuolations of glomeruli. In addition, the protective effect of royal jelly and cod liver oil resulted in a statistically non-significant reduction of tartrazine toxicity. In a study realized by ElDesoky et al. showed a dilation of blood sinusoids and central vein with hemorrhage and necrosis in the liver of rats exposed to this dye [55]. Interestingly, in a similar study of Hoseinpouran et al. onion (Allium cepa) added in the rat diet reduces the toxic effect of tartrazine on the enzymatic activity of antioxidants and biochemical serum parameters [21].

Applying daily doses of $0-7.5 \mathrm{mg} / \mathrm{kg} /$ day might produce neurotoxicity and a deficiency in the learning and 
memory process in rodents, due generation of reactive oxygen species and lipid peroxidation metabolites [58]. According to Aboel-Zahab et al. results, rats, which received a diet supplemented with a mixture of food dyes (such as sunset yellow, tartrazine, carmoisine, and brilliant blue) in different concentrations showed a significant increase in total serum lipids, COL, total protein and globulin serum transaminases [59]. Additionally, hematological analysis showed selective neutropenia and lymphocytosis, eosinophilia, and a significant decreased in hemoglobin concentration and RBC count. Histopathological investigations revealed congestions of blood vessels, areas of hemorrhage in both, renal and liver sections and brown pigment deposition in liver Kupffer cells. As reported by Sasaki et al. using a comet assay, tartrazine that was applied at a dose of $7.5 \mathrm{mg} / \mathrm{kg}$ could induce DNA damage in the colon of mice [22]. Nabila Mehedi et al. concluded that tartrazine applied in drinking water at the different low doses induced depression of body weight and adverse effects on the organs of Swiss mice [31]. Moreover, lesions in the brain, liver, and kidneys in animals treated with tartrazine were observed. The number of red blood cells, hemoglobin and hematocrit was increased, while the number of white blood cells was decreased in males of all groups. The excessive consumption of food dyes may cause problems for children's health.

In another study carried out by Mehedi et al. on Swiss albino mice it was observed that the excessive consumption of tartrazine could produce adverse effects on fertility, lowering sperm counts and increasing sperm abnormalities [60]. In this study, tartrazine was added at different doses $(0,0.1,1$, and $2.5 \%)$ in drinking water, for adult male mice during 13 weeks. Himri et al. reported that sulfanilic acid at dose of $3.75 \mathrm{mg} / \mathrm{kg}$ b.w. and tartrazine at dose of $10 \mathrm{mg} / \mathrm{kg}$ b.w. was able to trigger a morphologic change in red blood cells of rats, respectively modifying the discoidal form cell to an echinocytic shape [54]. Moreover, the liver weights, AST, CHL, CRE, GLU, TG and total protein in serum of the Wistar rats were increased significantly. Histopathological investigations showed changes that have occurred in kidneys as tubular dilatation, tubular degeneration, dilatation of the glomerular capillaries, intercapillary sclerosis, and atrophy of glomerulus. The author concluded that tartrazine does not only produced changes in the liver or kidney parameters, but also the impact of this dye becomes more dangerous when higher doses are applied, because it can induce oxidative stress by formation of free radicals.

In the study realized by Golli et al. [61], the food dye was administered orally at a dose of $300 \mathrm{mg} / \mathrm{kg} / \mathrm{b}$.w. to rats. However, Golli et al. [61] observed an increase in thrombocytes counts in rats and a dose of $300 \mathrm{mg} / \mathrm{kg} / \mathrm{b}$.w. of tartrazine was able to elevate the activity of hepatocellular enzymes facilitating changes in kidney biomarkers. On the other hand, peripheral lymphocytes and spleen $\mathrm{T}$ CD8-lymphocytes were reduced, suggesting the toxic potential of tartrazine on immune response, hepatic and renal functions. Furthermore, critical oxidative modifications in all analyzed organs were revealed due to the promotion of lipid peroxidation and the changes in endogenous antioxidant-defense enzymes. Therefore, the author concluded that sub-chronic exposure of tartrazine could produce deficiencies in blood parameters, immune-toxicity leading to renal and hepatic impairment by modifying the total equilibrium between oxidants and antioxidants [61].

\section{Conclusions}

Altogether, our results showed that tartrazine was able to generate histopathological changes, which caused certain tissue lesions of the liver, kidney, and spleen. The administration of this dye in the diet of rats can induce significant changes in all biochemical and hematological parameters of the blood. Notably, we elucidated the promising protective role of Blackthorn (Prunus spinosa) fine powder on hematological and biochemical parameters of blood, added in Wistar albino rats diet. On the other hand, fruit powder demonstrated non-significant protective effects for analyzed organs.

\section{Abbreviations \\ B.w.: body weight; EDTA: ethylenediaminetetraacetic acid; AST: aspartate ami- notransferase; ALT: alanine aminotransferase; GLU: glucose; COL: cholesterol; TG: triglyceride; CRE: creatinine; LYM\%: percentage of lymphocytes; RBC: red blood cells; HGB: hemoglobin concentration; HCT: hematocrit; MCV: corpus- cular volume; MCHC: corpuscular hemoglobin concentration; LYM: small/ medium lymphocytes; $\mathrm{MCH}$ : corpuscular hemoglobin; WBC: white blood cells; MPV: platelet volume; MO\%: relative percentage content of monocytes; NEU: contents of neutrophils; NE\%: relative (\%) content of neutrophils; RDW: red cell distribution width; PCT: represents plateletcrit; PDW: platelet distribution width; DW: dry weigh; C3GE: cyanidin-3-glucoside chloride; GAE: gallic acid.}

\section{Acknowledgements}

I would like to express my deepest gratitude to Mr. Liam Henry who as a good friend was always willing to help and give the best (grammar) suggestions. Also, I would like to thank Mr. Victor Lesco for general help. Finally, I wish to express my great appreciation to Mr. Colum Connolly for his valuable and constructive support during the development of this research paper. His willingness to give his time so generously has been very much appreciated.

\section{Authors' contributions}

IB, AC, CSM, ALA conceived and realized the experimental plan; harvested the organs of the animals; performed the statistical interpretation of the results; contributed to the final version of the manuscript. BS - gathered experimental samples; biochemical and hematological analysis of animal blood. VM, CR, ZM-housing and care of laboratory animals. MT_- performed histopathological image analysis. All authors read and approved the final manuscript.

\section{Funding}

This project is funded by the Ministry of Research and Innovation through Program 1-Development of the National Research and Development System, Subprogram 1.2-Institutional Performance-Projects for Financing the 
Excellence in CDI, Contract no. 37PFE/06.11.2018. Title of the project: "Increasing the institutional performance through consolidation and development of research directions within the USAMVCN".

\section{Availability of data and materials}

The data supporting the conclusions have been presented in the research paper.

\section{Competing interests}

The authors declare that they have no competing interests.

\begin{abstract}
Author details
1 Department of Toxicology, Faculty of Animal Science and Biotechnology, University of Agricultural Sciences and Veterinary Medicine, Calea Manastur 3-5, 400372 Cluj-Napoca, Cluj, Romania. ${ }^{2}$ Department of Physiopathology, Biology, Breading and Pathology of Laboratory Animals, University of Agricultural Sciences and Veterinary Medicine, Calea Manastur 3-5, 400372 Cluj-Napoca, Cluj, Romania. ${ }^{3}$ Department of Anatomy and Physiology, University of Agricultural Sciences and Veterinary Medicine, Calea Manastur 3-5, 400372 Cluj-Napoca, Cluj, Romania. ${ }^{4}$ Department of Pathology, Necropsy Diagnosis, Forensics, Oncology, University of Agricultural Sciences and Veterinary Medicine, Calea Manastur 3-5, 400372 Cluj-Napoca, Cluj, Romania. ${ }^{5}$ Department of Food Technology, University of Agricultural Sciences and Veterinary Medicine, Calea Manastur 3-5, 400372 Cluj-Napoca, Cluj, Romania. ${ }^{6}$ Department of Horse Breeding Technology, University of Agricultural Sciences and Veterinary Medicine, Calea Mănăștur 3-5, 400372 Cluj-Napoca, Cluj, Romania. ${ }^{7}$ Environment and Soil Science Department, University of Lleida, Av. Alcalde Rovira Roure 191, 25198 Lleida, Spain.
\end{abstract}

Received: 22 March 2018 Accepted: 15 July 2019

Published online: 09 August 2019

\section{References}

1. Tofana M (2006) Aditivi Alimentari Interactiunea cu Alimentul

2. Coroian A (2014) Toxicologia alimentelor. Manual Didactic

3. Grater WC (1976) Hypersensitive skin reactions to FD\&C dyes. Cutis 17:1163-1165

4. Safford RJ, Goodwin BF (1985) Immunological studies on tartrazine and its metabolites. I. Animal studies. Int Arch Allergy Appl Immunol. 77(3):331-336

5. Bhatia MS (2000) Allergy to Tartrazine in psychotropic drugs. J Clin Psychiatry 61(7):473-476

6. Ardern K, Ram F (2001) Tartrazine exclusion for allergic asthma. Cochrane Database Syst Rev. https://doi.org/10.1002/14651858.CD000460

7. Ishidate M, Sofuni T, Yoshikawa K (1981) Mutation, promotion and transformation in vitro, vol 27. Scientific Societies Press, Tokyo, pp 95-108

8. Ishidate M, Sofuni T, Yoshikawa K, Hayashi M, Nohmi T, Sawada M (1984) Primary mutagenicity screening of food additives currently used in Japan. Food Chem Toxicol 22(8):623-636. https://doi.org/10.1016/02786915(84)90271-0

9. Giri AK, Das SK, Talukder G, Sharma A (1990) Sister chromatid exchange and chromosome aberrations induced by curcumin and tartrazine on mammalian cells in vivo. Cytobios. 62(249):7-111

10. Stevenson DD (2014) Food allergy: adverse reaction to foods and food additives. Wiley-Blackwell, Hoboken, pp 377-385

11. Miller K (1982) Sensitivity to tartrazine. Br Med J. 285(6355):1597-1598

12. Novembre E, Dini L, Resti M, Vierucci A (1992) Unusual reactions to food additive. Pediatr Med Chir 14(1):39-42

13. Arnold LE, Lofthouse N, Hurt E (2012) Artificial food colors and attentiondeficit/hyperactivity symptoms: conclusions to dye for. Neurotherapeutics. 9(3):599-609. https://doi.org/10.1007/s13311-012-0133-x

14. Pohl R, Balon R, Berchou R, Yeragani VK (1987) Allergy to tartrazine in antidepressants. Am J Psychiatry. 144(2):237-238. https://doi.org/10.1176/ ajp.144.2.237

15. Safford RJ, Goodwin BF (1984) The effect of tartrazine on histamine release from rat peritoneal mast cells. Int J Immunopharmacol 6(3):40-233
16. Murdoch RD, Lessof MH, Pollock I, Young E (1987) Effects of food additives on leukocyte histamine release in normal and urticaria subjects. J R Coll Physicians Lond 21(4):251-256

17. Murdoch RD, Pollock I, Naeem S (1987) Tartrazine induced histamine release in vivo in normal subjects. J R Coll Physicians Lond 21(4):257-261

18. Schaubschläger WW, Schlaak M, Zabel P (1987) Tartrazine-induced histamine release from gastric mucosa. Lancet. 2(8562):800-801

19. Bent S, Wollgarten I, Schmutzler W (1993) The effects of food additives and aflatoxin B1 on histamine release from human mast cells. Agents Actions. 38(3-4):209-211. https://doi.org/10.1007/BF01996462

20. Authority EFSA (2009) Scientific opinion of the re-evaluation of tartrazine. EFSA J. 7(11):78. https://doi.org/10.2903/j.efsa.2009.1331

21. Hoseinpouran M, Khaki A, Nazem H (2015) Assessment of antioxidant properties of allium cepa on serum antioxidants and spermatogenesis after consuming tartrazine in rat. Crescent J Med Biol Sci 2(4):125-129

22. Sasaki YF, Kawaguchi S, Kamaya A, Ohshita M, Kabasawa K, Iwama K et al (2002) The comet assay with 8 mouse organs: results with 39 currently used food additives. Mutat Res. https://doi.org/10.1016/S1383 5718(02)00128-6

23. Farag IM, Aziz KA, El-Nahass E, Zaher M, Hegazy MA, Roshdy HM (2001) Cytogenetic studies on the effects of tartrazine, $\beta$-carotene and a mixture of both dyes on pregnant mice and their embryos. Bull Natl Res Centre Egypt 26:93-109

24. Ward NI (1997) Assessment of chemical factors in relation to child hyperactivity. J Nutr Environ Med 7:333-342. https://doi.org/10.1080/13590 849762466

25. Abdel-Aziz HM, Alazouny ZM, Abdelfadee KF, Abohashem AA (2019) Effect of tartrazine on thyroid gland of male rat and ameliorating role of curcumin (histological and immunohistochemical study). J Biochem Cell Biol 2:111

26. Elekima I, Nwachuku EO, Ben-Chioma AE (2017) Effect of tartrazine orally administered on thyroid hormones and thyroid stimulating hormone of albino rats. Ejpmr. 4(7):168-171

27. El-Keredy A (2017) Experiment on the genetic toxicity of tartrazine yellow and behavioral effects on Drosophila melanogaster. Egypt J Genet Cytol 46(1):33-42

28. Khayyat L, Essawy A, Sorour J, Soffar A (2017) Tartrazine induces structural and functional aberrations and genotoxic effects in vivo. Peerj. https:// doi.org/10.7717/peerj.3041

29. Hassan GM (2010) Effects of some synthetic coloring additives on DNA damage and chromosomal aberrations of rats. Arab J Biotech 13(1):13-24

30. Mpountoukas P, Pantazaki A, Kostareli E, Christodoulou P, Kareli D, Poliliou S, Mourelatos C, Lambropoulou V, Lialiaris T (2010) Cytogenetic evaluation and DNA interaction studies of the food colorants amaranth, erythrosine and tartrazine. Food Chem Toxicol 48(10):2934-2944. https:// doi.org/10.1016/j.fct.2010.07.030

31. Mehedi N, Mokrane N, Alami O, Ainad-Tabet S, Zaoui CA, Kheroua O et al (2013) A thirteen week ad libitum administration toxicity study of tartrazine in Swiss mice. Afr J Biotechnol. 12(28):4519-4529. https://doi. org/10.5897/AJB2013.12125

32. Abdelgayed SS, Ali AA, Eltawil OS, Bakeer AM (2016) Toxicological and histopathological studies on the effect of tartrazine in male albino rats. Int J Pharmacol Pharm Sci 10(8):527-532

33. Aliyazicioglu R, Yildiz O, Sahin H, Eyuboglu OE, Ozkan MT, Karaoglu SA et al (2015) Components and antioxidant activity of Prunus spinosa from Gumushane, Turkey. Chem Nat Compd. https://doi.org/10.1007/s1060 0-015-1278-8

34. Popescu I, Caudullo G (2016) Prunus spinosa in Europe: distribution, habitat, usage and threats. European Atlas of Forest Tree, pp 145

35. Veličković JM, Kostić DA, Stojanović GS, Mitić SS, Mitić MN, Randelović SS et al (2014) Phenolic composition, antioxidant and antimicrobial activity of the extracts from Prunus spinosa L. fruit. Hemind 68(3):297-303

36. Parvu C (2005) Enciclopedia plantelor. Plante din flora Romaniei, vol. 4. Tehnica

37. Alarcón R, de Santayana MP, Priestley C, Morales R, Heinrich M (2015) Medicinal and local food plants in the south of Alava (Basque Country, Spain). J Ethnopharmacol. 176(24):207-224. https://doi.org/10.1016/j. jep.2015 
38. Gegiu G, Branza AD, Bucur L, Grigorian M, Tache T, Badea V (2015) Contributions to the antimicrobial and antifungal study of the aqueous extract of Prunus spinosa L. Farmacia. 63(2):275-279

39. Losada-Barreiro S, Bravo-Díaz C (2017) Free radicals and polyphenols: the redox chemistry of neurodegenerative diseases. Eur J Med Chem 133:379-402. https://doi.org/10.1016/j.ejmech.2017.03.061

40. Miguel MG (2011) Anthocyanins: antioxidant and/or anti-inflammatory activities. J Appl Pharm Sci 1(06):07-15

41. Pinacho R, Cavero RY, Astiasarán I, Ansorena D, Calvo MI (2015) Phenolic compounds of blackthorn (Prunus spinosa L.) and influence of in vitro digestion on their antioxidant capacity. J Funct Foods 19:49-62. https:// doi.org/10.1016/j.jff.2015.09.015

42. Egea I, Sánchez-Bel P, Romojaro F, Pretel MT (2010) Six edible wild fruits as potential antioxidant additives or nutritional supplements. Plant Foods Hum Nutr 65:121-129. https://doi.org/10.1007/s11130-010-0159-3

43. Ruiz RBM, Ancos B, Sanchez MC, Ruiz VF, Mata MCS, Camara M, Tardio $J$ (2014) Wild blackthorn (Prunus spinosa L.) and hawthorn (Crataegus monogyna Jacq.) fruits as valuable sources of antioxidants. Fruits 69:61-73. https://doi.org/10.1051/fruits/2013102

44. Directive 2010/63/EU of the European parliament and of the council of 22 September 2010 on the protection of animals used for scientific purposes

45. Gonciarov M, Coman C (2015) General principles concerning the harmonization of Romanian Legislation with the European Union in the field of protection of animals used for scientific scope. Agric Agric Sci Procedia 6:336-341

46. Kassem MA, El-Sayed GO (2014) Adsorption of tartrazine on medical activated charcoal tablets under controlled conditions. J Environ Anal Chem. https://doi.org/10.4172/jreac.1000102

47. Bacioiu IG, Stoica L, Constantin C et al (2017) Removal of tartrazine from aqueous solution by adsorption on activated red mud. Water Air Soil Pollut 228:298. https://doi.org/10.1007/s11270-017-3469-3

48. Awareness Technology, Inc. (1997) Stat Fax ${ }^{\circledR} 1904$ Plus Owner's Manual

49. Bunea A, Rugină DO, Pintea AM, Sconța Z, Bunea Cl, Socaciu C (2011) Comparative polyphenolic content and antioxidant activities of some wild and cultivated blueberries from Romania. Not Bot Horti Agrobo. https://doi.org/10.15835/nbha3926265

50. Singleton VL, Orthofer R, Lamuela-Raventós RM, Lester P (1999) Analysis of total phenols and other oxidation substrates and antioxidants by means of Folin-Ciocalteu reagent. MethodsEnzymol 299:152-178

51. Giusti MM, Wrolstad RE (2001) Characterization and measurement of anthocyanins by UV-Visible spectroscopy. Curr Protoc Food Anal Chem Banner. 56:67. https://doi.org/10.1002/0471142913.faf0102s00
52. Arefin S, Hossain MS, Neshe SA, Rashid MO, Amin MT, Hussain S (2017) Tartrazine induced changes in physiological and biochemical parameters in Swiss albino mice, Mus musculus. Marmara Pharm J 21:564-569. https ://doi.org/10.12991/marupj.319304

53. Hasan KM, Tamanna N, Haque A (2018) Biochemical and histopathological profiling of Wistar rat treated with Brassica napus as a supplementary feed. Food Sci Hum Wellness 7:77-82. https://doi.org/10.1016/j. fshw.2017.12.002

54. Himri I, Bellahcen S, Souna F, Belmekki F, Aziz M, Bnouham M et al (2011) A 90 day oral toxicity study of tartrazine, a synthethic food dye, in Wistar rats. Int J Pharm Pharm Sci. 3(3):159-169

55. El-Desoky GE, Abdel-Ghaffar A, Al-Othman ZA, Habila MA, Al-Sheikh YA, Ghneim HK et al (2017) Curcumin protects against tartrazine-mediated oxidative stress and hepatotoxicity in male rats. Eur Rev Med Pharmacol Sci. 21(3):634-635

56. Al-Seeni MN, Rabey HE, Al-Hamed AM, Zamazami MA (2018) Nigella sativa oil protects against tartrazine toxicity in male rats. Toxicol Rep 5:146-155. https://doi.org/10.1016/j.toxrep.2017.12.022

57. Ghonimi WAM, Elbaz A (2015) Histological changes of selected Westar rat tissues following the ingestion of tartrazine with special emphasis on the protective effect of royal jelly and cod liveroil. J Cytol Histol. https://doi. org/10.4172/2157-7099.1000346

58. Gao Y, Li C, Shen J, An X, Jin H (2011) Effect of food azo dye tartrazine on learning and memory functions in mice and rats, and the possible mechanisms involved. J Food Sci. 76(6):125-129. https://doi.org/10.111 1/j.1750-3841.2011.02267.x

59. Aboel-Zahab H, El-Khyat Z, Sidhom G, Awadallah R, Abdel-AI W (1997) Physiological effects of some synthetic food colouring additives on rats. Boll Chim Farm 136(10):615-627

60. Mehedi N, Ainad-Tabet S, Mokrane N, Addou S, Zaoui C, Kheroua O et al (2009) Reproductive toxicology of tartrazine (FD and C Yellow No 5) in SwisAlbino mice. Am J Pharmacol Toxicol 4(4):130-135. https://doi. org/10.3844/ajptsp.2009.130.135

61. Golli NE, Bini-Dhouib I, Jrad A, Boudali I, Nasri B, Belhadjhmida N et al (2016) Toxicity Induced after subchronic administration of the synthetic food dye tartrazine in adult rats, role of oxidative stress. Recent Adv Biol Med 2:20-28. https://doi.org/10.18639/RABM.2016.02.284474

\section{Publisher's Note}

Springer Nature remains neutral with regard to jurisdictional claims in published maps and institutional affiliations.
Ready to submit your research? Choose BMC and benefit from:

- fast, convenient online submission

- thorough peer review by experienced researchers in your field

- rapid publication on acceptance

- support for research data, including large and complex data types

- gold Open Access which fosters wider collaboration and increased citations

- maximum visibility for your research: over $100 \mathrm{M}$ website views per year

At BMC, research is always in progress.

Learn more biomedcentral.com/submissions 